\title{
Elemen Dakwah dalam Siri Animasi Ummi: Ceritalah pada Kami
}

\author{
Siti Aisyah Yap Abdullah \\ Universiti Malaya, sitiaisyah.yap@gmail.com
}

\begin{abstract}
Abstrak
Pendekatan dakwah yang tepat terhadap sasaran memerlukan para da'i berusaha untuk menyusun strategi dakwahnya agar penyampaian tersebut mudah difahami dan diterima. Tujuan kajian ini berkaitan dengan elemen dakwah yang terdapat di dalam siri animasi Ummi: Ceritalah pada Kami (UCPK) dari sudut sumber rujukan, isi kandungan, pendekatan dan gaya persembahan. Hasil dapatan kajian mendapati bahawa siri UCPK ini menepati elemen dakwah Islamiyyah yang mengajak para penonton untuk memahami ajaran Islam dengan mudah sambil berhibur di samping turut mempunyai rangsangan psikologi yang positif.
\end{abstract}

Kata kunci: elemen dakwah, Ummi: Ceritalah pada Kami, strategi dakwah

\section{Da'wah Element in the Animated Series Ummi: Ceritalah pada Kami}

\section{Abstract}

Preaching with the right approach to the audience requires on preachers to strategize their method of deliver the message to be easily understood and accepted. The aim of this study deals with several elements that are present in the animated series Ummi: Ceritalah pada Kami (UCPK) from the point of referral sources, content, approach and style of presentation. The findings for this animated series fulfils of Islamic element that summons the audience to understand the teachings of Islam with ease while being entertained and also having a positive psychological boost.

Keywords: element of da'wah, Ummi: Ceritalah pada Kami, da'wah strategy

\section{Pendahuluan}

Walaupun secara ilmiah perkataan 'Animasi Dakwah' masih belum diterima pakai secara meluas dalam mana-mana terma penulisan dakwah sebagai suatu definisi khusus, maka secara praktikal dalam bidang dakwah ia telah diwujudkan secara tidak langsung dari pihak penerbit animasi dakwah itu sendiri. Hal ini kerana animasi merupakan medium pelaksana aktiviti kandungan dakwah. Secara umumnya perkataan dakwah membawa maksud 
mengajak atau menyeru sesama manusia kepada cara hidup Islam. ${ }^{1}$ Animasi pula merupakan suatu gambaran ciptaan yang digerakkan mengikut hasil daya kreativiti manusia melalui alatan teknologi berkomputer ${ }^{2}$. Gabungan perkataan Animasi Dakwah boleh diistilahkan sebagai hasil gambaran multimedia yang mengajak manusia kepada jalan Allah SWT.

Melalui pendekatan ini, animasi diibaratkan seperti jasad dan dakwah pula sebagai roh yang bersatu dan saling memerlukan untuk tujuan penyampaian dakwah dapat dilaksanakan. Dakwah animasi boleh digolongkan dalam kategori dakwah secara berhikmah kerana ia menggunakan pendekatan psikologi yang menarik untuk merangsang deria sasaran seperti pendengaran, penglihatan dan pemikiran. Oleh sebab yang demikian, isi kandungan animasi boleh diubah ke dalam pelbagai bidang seperti pendidikan, kejuruteraan, penyiaran, latihan, perubatan, sains, perundangan, senibina dan arkeologi ${ }^{3}$.

Tarikan yang terdapat dalam animasi dakwah sesuai diadaptasi sebagai suatu penontonan masa kini kepada golongan kanak-kanak secara khasnya yang harus dilihat bukan sebagai hiburan semata-mata, tetapi juga sebagai alat untuk santapan ilmu pengetahuan dan pengisian rohani. Oleh itu penyampaian animasi memerlukan isi kandungan yang berteraskan ajaran Islam seperti pengenalan ilmu akidah, syariat dan akhlak. Olahan kefahaman isi kandungan animasi mengikut kreativiti penerbit dalam menterjemahkan penyampaiannya yang berbentuk hiburan yang santai adalah amat penting supaya maklumat mudah dicerna oleh penonton.

\section{Latar Belakang Ummi: Ceritalah pada Kami (UCPK)}

UCPK ialah cerita yang berkisarkan mengenai watak Ummi yang merupakan pendidik di sebuah rumah transit penjagaan kanakkanak yang antaranya ialah Alif, Putri, Atan, Hana dan Aiman. Beliau sering memberi nasihat sambil bercerita mengenai kisah-

1 Ab. Aziz Mohd Zin, Pengantar Dakwah Islamiah (Kuala Lumpur: Penerbit Universiti Malaya, 1997), 2.

2 Merriam-Webster. Online Dictionary. United States: An Encyclopedia Britannica, 1996, dicapai 25 Mac 2015, http://www.merriamwebster.com/dictionary/animated\%20cartoon

3 Jamalludin Harun dan Zaidatun Tasir. Animasi dari Helaian kertas ke Skrin Digital (Selangor: Venton Publishing, 2005), h. 16-27. 
kisah teladan mengenai rasul dan sahabat kepada kanak-kanak tersebut. Secara keseluruhan, plot cerita siri UCPK ini terbahagi kepada 3 segmen utama iaitu pembuka dan penutup oleh Puan Nora Ariffin dalam bentuk video klip, kisah teladan dan kalimah pilihan. Masa tayangan secara purata adalah selama 22 minit.

Gambar 1: Segmen utama yang terdapat dalam animasi siri UCPK, pengenalan, kisah teladan dan kalimah pilihan.

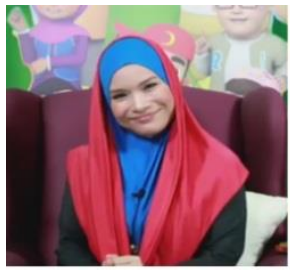

Pengacara pembuka dan penutup cerita oleh Puan Nora Ariffin

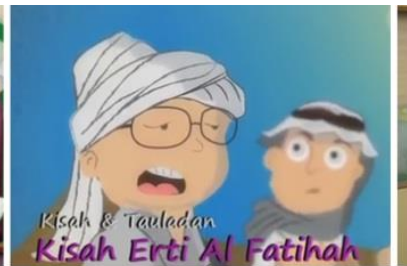

Segmen Kisah Teladan

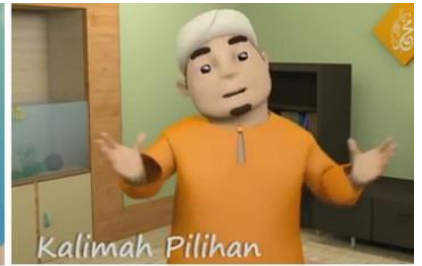

Segmen Kalimah Pilihan

Sumber: Hud Hud Media Sdn Bhd, 2011.

Perjalanan cerita yang ditayangkan dalam UCPK dimulakan dengan bahagian pengenalan yang dikendalikan oleh Puan Nora Ariffin dalam bentuk video. Setiap episod mempunyai tajuk yang berlainan. Selepas itu, segmen kisah teladan yang dikendalikan oleh watak Ummi secara suara latar belakang sarat dengan kisahkisah yang berkait dengan tajuk cerita untuk anak-anak didiknya iaitu Alif, Hana, Aiman, Atan dan Putri.

Segmen kalimah pilihan yang dikendalikan oleh watak Ustaz Syakir kemudiannya menyusul sebagai petanda di penghujung jalan cerita bagi setiap episod UCPK. Kebiasaannya Ustaz Syakir akan memberikan beberapa perkataan yang mudah dan ringkas beserta dengan contoh penerangan isi yang lengkap dan mudah difahami oleh penonton. Watak Pengacara yang juga dikendalikan oleh Puan Nora Ariffin akan muncul membuat kesimpulan untuk seluruh cerita tersebut.

\section{Elemen Dakwah dalam Siri Animasi UCPK}

Elemen-eleman animasi dakwah yang terkandung dalam siri UCPK akan dianalisis berdasarkan kepada beberapa kategori. Ia melibatkan sumber rujukan, isi atau mesej kandungan, cara 
pendekatan dan gaya persembahan. Berikut merupakan hasil dari analisis tersebut:

\section{Sumber Rujukan}

Hasil dari penelitian terhadap keseluruhan 11 episod, terdapat pelbagai sumber rujukan telah digunakan. Antaranya ialah alQuran, hadith, kisah para rasul, sirah islam, kisah para sahabat, teladan masyarakat dan kisah motivasi. Berikut merupakan bukti sumber rujukan penggunaannya dalam episod-episod tertentu seperti:

Gambar 2: Menunjukkan surah-surah dalam al-Quran yang digunakan sebagai rujukan dalam cerita.

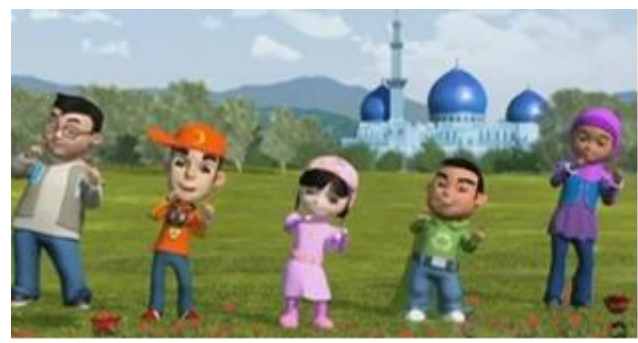

Episod 1: Erti al Fatihah

Masa: 05:01-06:13

Lagu: Segala puji bagi Allah, Tuhan semesta alam, Maha Pemurah lagi Maha Penyayang, Yang menguasai Hari Pembalasan, Hanya kepadaMu, Ya Allah, Kami menyembahMu, Ya Allah, Hanya kepadaMu kami mohon pertolongan, Tunjukilah kami Jalan yang lurus, Iaitu jalan-jalan orang yang Kau kurniakan nikmat kepada mereka, Bukan jalan yang dimurkai, Dan bukan pula Jalan mereka yang sesat...

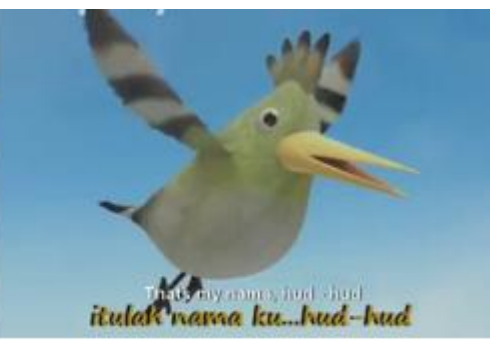

Episod 4: Sang Perisik Masa: 05:09-05:30

Lagu: Namaku disebut dalam al-Quran, Ayat 20 dari surah an-Nam1, Aku hampir disembelih.oleh Nabi Sulaiman Alaihissalam, Tetapi Kisah Ratu Balqis yang cantik berseri...telah pun menyelamatkan nyawaku...

Sumber: Hud Hud Media Sdn Bhd, 2011.

Surah al-Fātiḥạ̣ merupakan asas bacaan dalam amalan ibadat seorang Muslim. Ia wajib dibaca dalam setiap rakaat ketika melakukan solat seperti mana menurut al-Shāfi'‘̄i dan para ulama ${ }^{4}$. Mengenai kisah dua sahabat nabi yang masuk ke sebuah perkampungan Arab dan berjaya menyembuhkan ketua kampung

4 M. Abdul Ghaffar E.M, Abdurrahim Mu'thi, Abu Ihsan Al-Atsari, Tafsir Ibnu Katsir (Lubaabut Taafsiir Min Ibni Katsiir) (Indonesia: Pustaka Imam AsySyafi'i, 2007) 1: 12. 
dengan bacaan surah al-Fātihạh atas izin Allah SWT serta mendapat beberapa ekor kambing sebagai hadiah adalah dari riwayat Muslim dan Abū Dāwud ${ }^{5}$. Manakala dalam al-Quran surah al-Naml ayat 20 sehingga ayat 44 menukilkan kisah ketaatan seekor burung Hud Hud yang menjadi sebahagian tentera Nabi Sulaiman a.s telah menemui sebuah kerajaan yang menyembah Matahari diketuai oleh seorang Ratu bernama Balqis. Atas seruan dakwah yang disampaikan oleh Nabi Sulaiman a.s, akhirnya Ratu Balqis dan pengikutnya mengakui Allah swt adalah yang berhak disembah. Oleh kerana Hud Hud adalah penyeru kepada kebaikan dan beribadah kepada Allah, maka ia dilarang dari dibunuh ${ }^{6}$.

Gambar 3: Rujukan yang menggunakan hadith daif mengenai kisah al-Qamah.

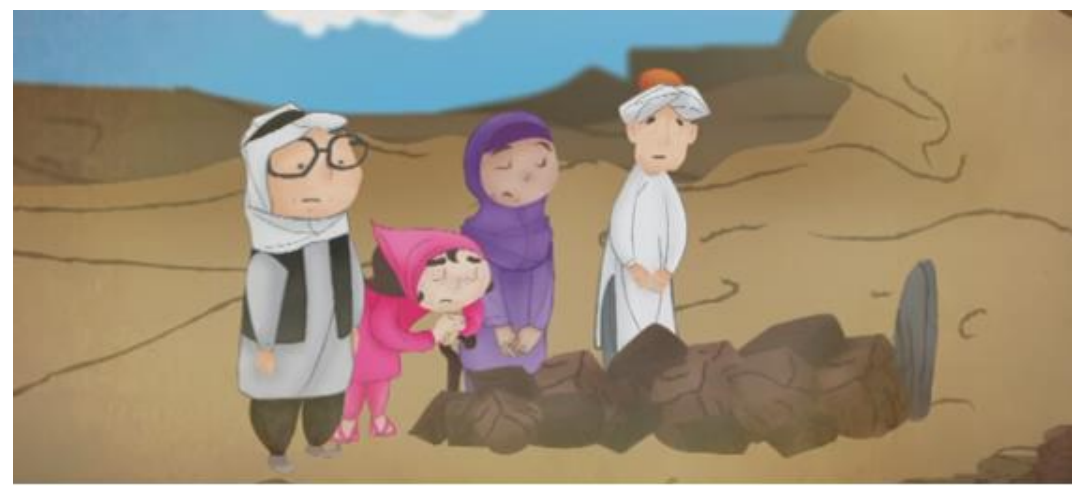

Episod 2: Si Tanggang Moden

Masa: 15:16-15:52

VO Ummi: Pada hari pengkebumian al Qamah, Rasulullah SAW bersabda, "Wahai sekalian orangorang Muhajirin dan Ansar, sesiapa yang mengutamakan isterinya daripada ibunya, maka wajib ke atasnya laknat Allah, para malaikat dan sekalian manusia. Allah tidak akan menerima segala amalannya sama ada yang sunat ataupun yang fardhu, melainkan setelah dia bertaubat kepada Allah Taala, berbuat baik kepada ibunya dan mencari keredhaannya, maka redha Allah Azza Wajalla terletak kepada redha ibunya, dan kemurkaan Allah itu terletak kepada kemurkaan ibunya."

Sumber: Hud Hud Media Sdn Bhd, 2011.

5 M. Abdul Ghaffar E.M, Abdurrahim Mu'thi, Abu Ihsan Al-Atsari, Tafsir Ibnu Katsir, 9-10.

6 Hadith riwayat Ahmad, Abū Dāwud dan Ibn Majah, bahawa Abū Hurayrah berkata, "Nabi melarang membunuh empat binatang, antaranya ialah semut, lebah, Hud hud dan burung Shurad", Hadith tersebut berasal dari sahabat Ibn'Abbas r.a. 
Darjat bagi hadith mengenai kisah al-Qamah ini telah disepakati sebagai daif oleh para ulama seperti Ahmad, al-Qā'ilī,

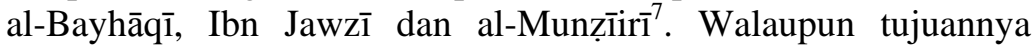
adalah untuk menggalakkan anak-anak supaya berbakti kepada ibu dan bapa, tetapi tetap tidak membolehkan kita untuk menyebarkan sebarang bentuk pendustaan terhadap Rasulullah ${ }^{8}$. Terdapat hadith sahih yang boleh menggantikan tema keutamaan berbakti kepada ibu dan bapa seperti Hadis Hasan Sahih yang dilaporkan oleh Ibn Umar, Rasulullah pernah menyatakan di antara golongan yang tidak akan dipandang oleh Allah pada hari akhirat kelak dan tidak akan masuk syurga ialah mereka yang menderhakai ibu bapanya ${ }^{9}$.

Gambar 4: Sirah Islam yang merujuk kepada Para Sahabat Rasulullah SAW seperti Abu Bakar, Bilal bin Rabah dan Umar alKhattab digunakan sebagai sumber penceritaan.

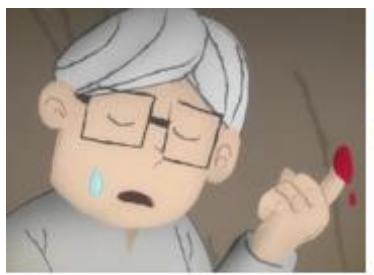

Episod 3: Rakan Sejati

Masa: 13:03-13:16

VO Ummi: Abu Bakar melihat ke arah lubang gua dan risau. Dia menahan bisa patukan ular sehingga menitiskan air mata.

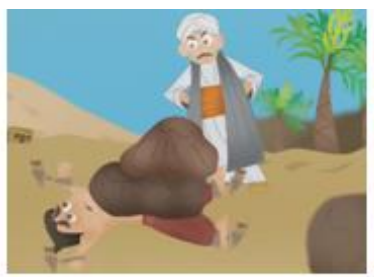

Episod 5: Iman Mengangkat Martabat

Masa: 10:09-10:16

VO Ummi: Walaupun beliau diseksa, Bilal masih kuat keimanannya kepada Allah SWT.

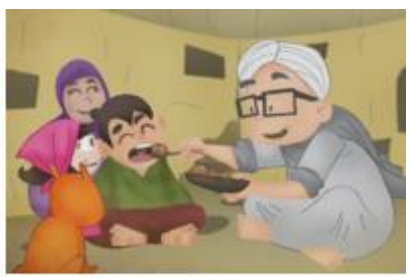

Episod 6: Pemimpin Terpuji Masa: 12:04-12:21

VO Ummi: Umar kemudiannya datang semula ke rumah orang miskin tersebut. Dia memberikan salam, masuk ke dalam rumah dan memasak. Dia juga menyuapkan makanan kepada anak-anak tersebut.

Sumber: Hud Hud Media Sdn Bhd, 2011.

Para sahabat merupakan tokoh yang wajar dicontohi kerana mempunyai sahsiah peribadi yang kuat berserta dengan keimanan yang kukuh terhadap Allah SWT. Antara beberapa tokoh yang

7 Lc Ahmad Sabiq, "Kisah al Qamah Durhaka Kepada Ibunya", laman sesawang Kisah Muslim, dikemaskini 25 November 2010, dicapai 23 Mac 2016, https://kisahmuslim.com/84-alqomah-durhaka-kepada-ibu.html.

8 Abdul Razak Muthalib, 40 Hadis Palsu Popular (Selangor: PTS Islamika Sdn Bhd. 2011), 221.

9 Abdul Razak Muthalib, 40 Hadis Palsu Popular, 222. 
dikemukakan ialah Abu Bakar ${ }^{10}$ Bilal bin Rabah ${ }^{11}$ dan Umar alKhattab $^{12}$. Selain keimanan yang kukuh, mereka juga merupakan tokoh yang terkenal dengan sifat yang bertanggungjawab, amanah, bijak, merendah diri dan lain-lain sifat yang terpuji.

Gambar 5: Kisah para rasul dijadikan sebagai rujukan dalam cerita.

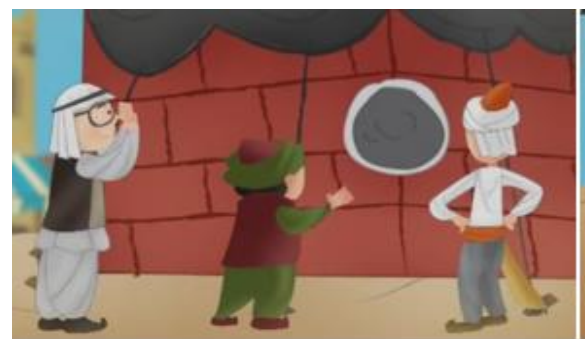

Episod 7: Terima Kasih Cikgu

Masa: 12:21-12:29

VO Ummi: Alhamdulillah, semua ketua kabilah berpuas hati dengan sumbangan mereka meletakkan hajarul aswad tanpa sebarang pertumpahan darah.

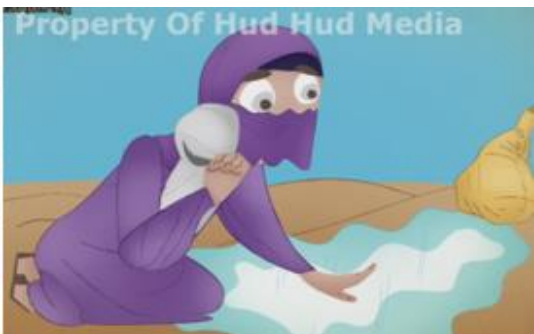

Episod 9: Telaga Zam Zam Masa: $15: 16-15: 26$

VO Ummi: Hajar cuba menghentikan aliran air tersebut dengan menyebut "Zum Zum" dalam Bahasa Arab bermaksud berhenti. Walau bagaimanapun, air tersebut terus mengalir.

Sumber: Hud Hud Media Sdn Bhd, 2011.

Peristiwa perletakan batu hitam ${ }^{13}$ atau dipanggil Hajarul Aswad selepas selesai pembinaan Kaabah hampir menimbulkan pertumpahan darah antara kabilah arab di Kota Mekah sebelum diselesaikan oleh Muhammad bin Abdullah. Berdasarkan sifat baginda yang amanah, jujur lagi bijaksana dipercayai oleh seluruh penduduk Kota Mekah untuk dilantik menjadi hakim bagi menyelesaikan pertelingkahan tersebut. Telaga Zam Zam pula merupakan sebahagian dari sejarah pembinaan Kota Mekah selain dari terkenal dengan tempat menunaikan fardhu haji bagi umat

${ }^{10}$ Ummu Fatimah Az-Zahra. 1998. Riwayat Para Sahabat Rasulullah SAW. Johor: Perniagaan Jahabersa. h, 538.

11 "Bilal Ibn Rabah", laman sesawang Islamreligion.com, dikemaskini 2013, dicapai $15 \quad$ April 2016, http://islam114.com/main/wpcontent/uploads/2013/07/Bilal-Ibn-Rabah.pdf.

12 Abdul Latip Talib, Umar Al Khattab - Reformis Dunia Islam (Selangor: PTS Litera Utama Sdn Bhd., 2010), 286-289.

13 Tarikuddin bin Haji Hassan, Kisah 25 Nabi-Nabi (Johor Bahru: Perniagaan Jahabersa, 2006), 352-353. 
Islam dari seluruh dunia. Ia juga mengabdikan kisah pengorbanan Hajar $^{14}$, isteri Nabi Ibrahim yang ditinggalkan di tengah padang pasir atas wahyu Allah SWT. Berkat tawakal Hajar yang tinggi kepada Allah SWT, akhirnya muncul pancaran air yang dinamakan Zam Zam dan masih lagi mengalir sehingga ke hari ini.

Gambar 6: Kisah teladan yang digunakan sebagai rujukan dalam penceritaan.

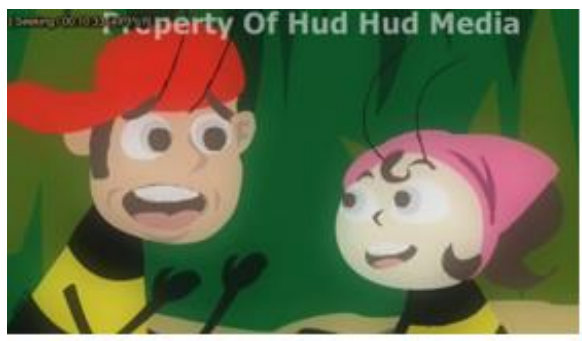

Episod 8: Lebah Membawa Manfaat

Masa: 10:38-10:57

Ferra: Bukankah kita membantu mereka melakukan pendebungaan tanaman untuk kegunaan mereka juga? Madu kan bermanfaat dalam makanan dan perubatan?

Apis: Mereka mungkin tak sedar, Ferra. Mereka besar dan kita cumalah makhluk yang kecil.

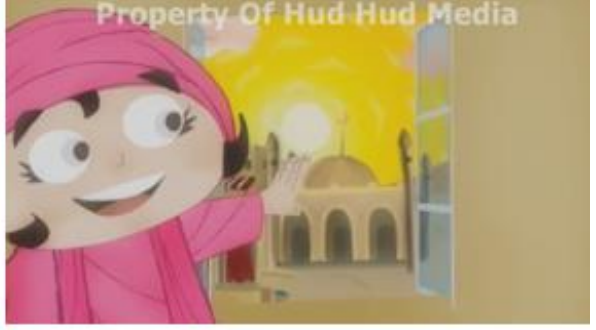

Episod 11: Bunyi yang Indah

Masa: 13:12-13:29

Penasihat 4: Apabila kita mulai berpuasa dan tidak boleh minum dan makan sepanjang hari, bukankah Bunyi Azan Maghrib merupakan bunyi yang paling indah di dunia?

Sumber: Hud Hud Media Sdn Bhd, 2011.

Manfaat madu yang dihasilkan oleh lebah sememangnya membawa khasiat yang tinggi dalam bidang pemakanan, kecantikan dan kesihatan ${ }^{15}$ untuk manusia. Kebaikannya dirakam dalam al-Quran surah al-Nahl ayat 68-69. Kisah lebah yang membawa manfaat diadaptasi oleh HHM ke dalam bentuk cerita yang lebih mudah difahami oleh kanak-kanak supaya menghargai makhluk kecil ciptaan Allah SWT. Kisah teladan lain pula menggambarkan Sultan dari kerajaan Persia pernah memberikan sebuah teka-teki kepada para penasihatnya mengenai bunyi yang

14 “Asal Mula Air Zam-Zam dan Manfaatnya”, dikemaskini 2011-2014, dicapai 15 April 2016, http://dakwahsyariah.blogspot.my/2013/09/asal-mula-air-zamzam-dan-manfaatnya.html.

${ }^{15}$ Danial Zainal Abidin, Perubatan Islam dan Bukti Sains Moden (Selangor: PTS Millennia Sdn Bhd. 2015), 70-76. 
paling indah di dunia ${ }^{16}$. Teka teki tersebut akhirnya dipersetujui jawapannya oleh semua jemputan penasihat keempat termasuklah sultan apabila berkumandangnya bunyi azan Maghrib selepas kesemua mereka berpuasa menahan lapar dan dahaga sepanjang hari walaupun dipersembahkan dengan bunyi-bunyian menarik yang lain.

Gambar 7: Kisah motivasi yang sebenar diolah dalam lakaran melalui penceritaan.

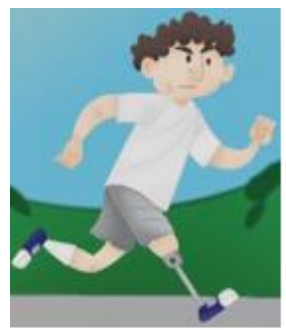

Lakaran Terry Fox

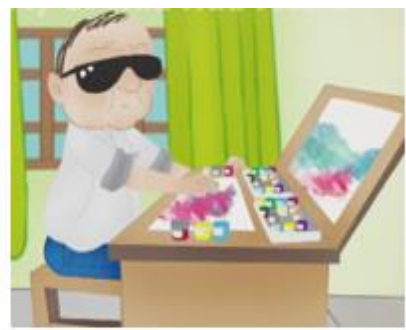

Lakaran Esref Armagan

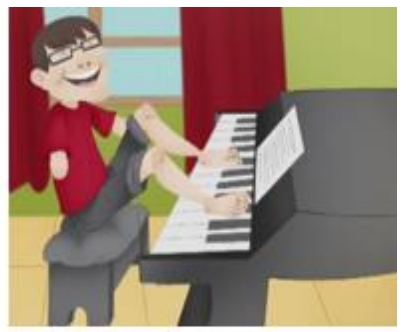

Lakaran Liu Wei

Sumber: Hud Hud Media Sdn Bhd, 2011.

Rujukan motivasi membawakan kisah Terry Fox, ahli sukan kurang upaya ${ }^{17}$ dari Kanada, Esref Armagan, pelukis tanpa penglihatan ${ }^{18}$ dari Turki dan Liu Wei pemain piano tanpa tangan. ${ }^{19}$ Mereka mampu melakukan perkara-perkara yang luar biasa walaupun mengalami kecacatan fizikal kerana mempunyai kekuatan minda dan matlamat yang teguh. Kisah sebenar ini wajar

${ }^{16}$ Kate Dudding, "The Sweetest Sound", Laman sesawang katedudding.com, dicapai 15 April 2016, http://www.katedudding.com/sweetest_sound.shtml

17 "A Legacy that Touched the Heart of a Nation: Featuring Terry Fox Athlete Article", Youth Education Programs, Honouring the Past. Inspiring the Future, dicapai $15 \quad$ April 2016, http://www.heroinyou.ca/wpcontent/uploads/2013/11/Terry-Fox-Athlete-Article.pdf

${ }^{18}$ John M. Kennedy and Igor Juricevic, Esref Armagan and Perspective in Tactile Pictures (Kanada: University of Toronto, Department of Psychology, t.t.).

19 Ji Chen (Associated Press Researcher), "Liu Wei, Armless Pianist, Plays With His Toes, Wows Audience (VIDEO)", TheHuffingtonPost.com Inc, dikemaskini 25 Mei 2011, dicapai 15 April 2016, http://www.huffingtonpost.com/2010/08/27/chinese-musician-with-no_n_696914.html. 
dijadikan sebagai sumber inspirasi supaya orang lain juga turut boleh berusaha menggapai impian dan cita-cita yang tersendiri.

\section{Isi Kandungan}

Isi kandungan dalam animasi dakwah memerlukan penyampaian mesej yang bermanfaat kepada penonton selain dari menganggap ia sebagai bahan hiburan. Dari sudut pandangan Islam, hiburan adalah harus dengan syarat secara tidak berlebihan ${ }^{20}$. Oleh itu, pengisian kandungannya memerlukan unsur-unsur asas ajaran Islam yang mengandungi akidah, syariat dan akhlak sebagai pengisian kerohanian. Berikut merupakan unsur-unsur isi kandungan Islam yang terdapat dalam siri UCPK:

\section{i. Akidah}

Akidah bermaksud rukun agama yang menjadi asas kepada keimanan yang diyakini ${ }^{21}$ dan perkataan lain yang seumpama dengan akidah juga ialah agama yang membawa maksud kepercayaan dan keyakinan terhadap ajaran atau fahaman tertentu ${ }^{22}$. Dari sudut istilah bagi akidah Islam pula bermaksud kepercayaan dengan tunduk dan patuh kepada Allah $\mathrm{SWT}^{23}$. Inti akidah yang pertama dalam rukun Islam ialah mengucap dua kalimah syahadah. Ia mengandungi erti persetujuan, pengakuan dan keyakinan ${ }^{24}$ akan kebenarannya sebagai orang yang beragama Islam dengan ucapan "Aku bersaksi tiada tuhan selain Allah dan Muhammad pesuruh Allah". Ia juga adalah ucapan yang membawa maksud mengabdikan diri hanya kepada Allah sematamata, tidak mensyirikkanNya dengan sesuatu ${ }^{25}$ dan tidak tunduk selain dariNya. Kepatuhan dalam Islam terdiri dari pelbagai bentuk sama ada secara niat, ucapan atau perbuatan. Bukti unsur

${ }^{20}$ Yusuf al-Qaradhawi, Fiqh Hiburan dan Rekreasi (Selangor: PTS Islamika Sdn Bhd., 2014), 5.

${ }^{21}$ Hajah Noresah bt. Baharom, Kamus Dewan Edisi Keempat (Kuala Lumpur: Dewan Bahasa dan Pustaka, 2015), 25.

${ }^{22}$ Ahmad Tarmizi Talib, Tamadun Islam (Serdang: Penerbit Universiti Putra Malaysia. 1997), 1.

${ }^{23}$ Ahmad Tarmizi, Tamadun Islam, 1.

${ }^{24}$ Abdul Karem Zaidan, Dasar-Dasar Ilmu Da'wah, terj. H.M Asywadi Syukur Lc. Selangor: Dewan Pustaka Fajar, 2007), 1:14.

${ }^{25}$ Fathi Yakan, Apa Ertinya Saya Menganut Islam? (Kuala Lumpur: Pustaka Salam Sdn Bhd., 2000), 22. 
akidah yang terkandung dalam semua siri UCPK adalah seperti dalam paparan berikut:

Gambar 8: Contoh paparan unsur-unsur akidah dalam siri UCPK.

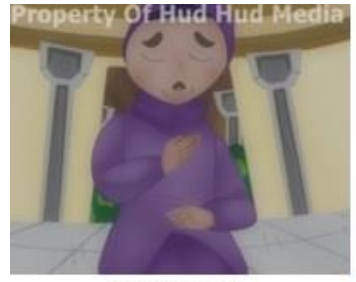

GAMBAR 8 A

Episod 4: Sang Perisik

Masa: 15:07-15:17

Ratu Balqis: Oh Tuhan, aku telah berbuat zalim kepada diriku sendiri. Aku menyerahkan diri dan jiwaku untuk petunjuk Tuhanmu dan tunduk kepadamu sebagai pesuruhNya.

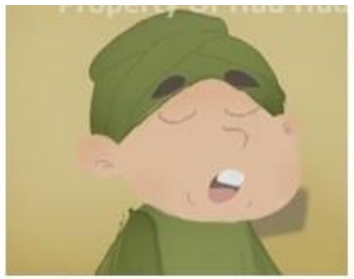

GAMBAR 8 B

Episod 5: Iman Mengangkat Martabat

Masa: 09:27-09:40

Bilal: Ashhadu alla Ilaha Illallah,

Wa ashhadu anna Muhammadar

Rasulullah.

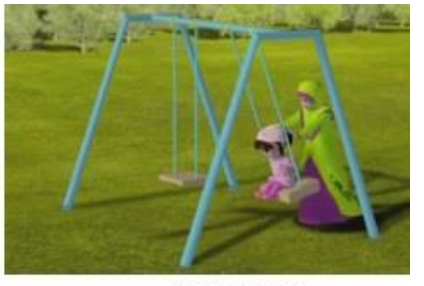

GAMBAR 8 C

Episod 6: Pemimpin Terpuji Masa: 01:57-12:49

Ummi dan Putri:

Subhanallah Walhamdulillah Wala Ilaha Illallah Allahu Akbar (4 kali)

Sumber: Hud Hud Media Sdn Bhd, 2011.

Terdapat beberapa babak akidah yang digambarkan melalui niat, ucapan dan perbuatan dalam siri UCPK ini. Antara paparan berbentuk niat seperti dalam gambar 8 A dalam episod Sang Perisik, watak Ratu Balqis yang berniat untuk menerima seruan dakwah Nabi Sulaiman AS untuk mentauhidkan Allah SWT. Kisah ini bermula apabila burung Hud Hud melaporkan kepada Nabi Sulaiman a.s mengenai keadaan Kerajaan Saba yang dilihat tidak beriman kepada Allah.

Dalam episod Iman Mengangkat Martabat yang terdapat dalam gambar 8 B memaparkan watak Bilal Rabah mengucap dua kalimah syahadah sebagai pengakuan untuk beragama Islam. Keimanan Bilal yang teguh dalam mentauhidkan Allah SWT melalui peribadi yang dimiliki olehnya telah menjadi contoh kepada seluruh umat Islam. Beliau juga merupakan antara sahabat Rasulullah SAW yang terkenal sehingga ke hari ini dengan tugasnya menyeru orang ramai mengerjakan solat sebagai muazin.

Manakala gambar $8 \mathrm{C}$ dalam episod Pemimpin Terpuji, kelihatan Ummi dan Putri sedang berzikir memuji kebesaran Allah. Hal seperti ini menggambarkan kelakuan yang berakidah sebagai amalan harian dalam kehidupan sebagai seorang yang 
beragama Islam. Ia juga menunjukkan bahawa amalan ibadah boleh dilakukan dalam pelbagai bentuk selain dari ibadah khusus seperti solat.

\section{ii. Syariat}

Menurut Kamus Dewan, syariat bermaksud hukum Islam $^{26}$. Ia merupakan panduan hak hidup secara individu dan berkumpulan ${ }^{27}$ serta berkait dengan akidah yang bersumberkan al-Quran dan Sunnah sebagai rujukan. Syariat tersebut mengandungi pelbagai aspek antaranya seperti Ibadat, Muamalat, Munakahat dan Jenayat.

Pendedahan ilmu syariat kepada kanak-kanak di awal usia adalah wajar supaya mudah dan biasa untuk diamalkan di kemudian hari selain dari bertujuan sebagai pendidikan jati diri sebagai seorang muslim. Contoh mudah pendedahan tersebut seperti solat, puasa, membaca al-Quran dan berzikir sebagai Ibadah khusus, manakala contoh ibadah umum pula ialah pemakanan yang halal, bersedekah, menjaga kesihatan dan membantu orang lain dalam kesusahan. Antara unsur-unsur syariat yang dipaparkan dalam siri UCPK adalah seperti berikut:

Gambar 9: Contoh kandungan unsur syariat dalam siri UCPK.

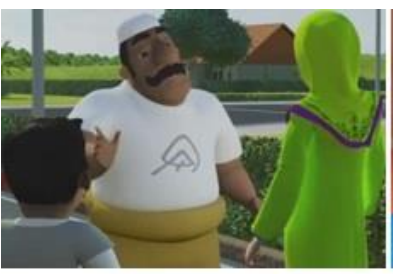

GAMBAR 9 A

Episod 3: Rakan Sejati

Masa: 07:08-07:20

Uncle Maideen: Semua roti suci, bersih dan halal...Insyaallah...

Ummi: Alhamdulillah. Bagus tu Uncle

Maideen. Sangat penting untuk

memastikan kesemuanya halal.

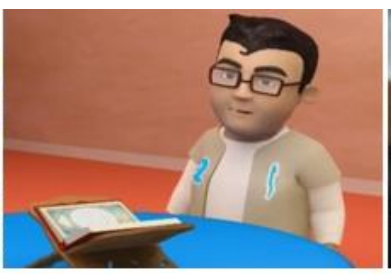

GAMBAR 9 B

Episod 8: Lebah Membawa Manfaat Masa: 13:45-14:07

Alif: Saya tak dapat simpan apa-apa hari ni, Ummi. Saya baru sahaja ternampak pengemis mendukung bayinya. Saya rasa kesian dan telah memberikan duit simpanan saya. Saya minta maaf, Ummi.

Ummi: Tak mengapa Alif. Ia Bagus. Memberi derma atau sedekah, adalah amalan yang baik dan disukai Allah.

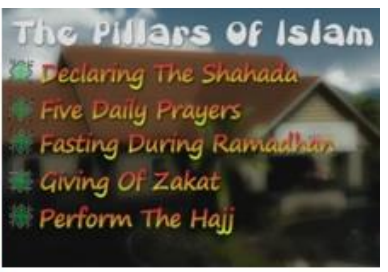

GAMBAR 9 C

Episod 9: Telaga Zam Zam Masa: 02:57-03:12

Alif: Nombor 1 , mengucap dua kalimah syahadah, nombor 2 , solat 5 kali sehari, nombor 3 , berpuasa di Bulan Ramadhan, nombor 4, menunaikan zakat dan nombor 5 menunaikan fardhu haji bagi yang berkemampuan.

Sumber: Hud Hud Media Sdn Bhd, 2011.

${ }^{26}$ Hajah Noresah bt. Baharom, Kamus Dewan Edisi Keempat, 1559.

${ }^{27}$ Ahmad Tarmizi Talib, Tamadun Islam, 87. 
Syariat yang dipaparkan dalam siri UCPK ini merangkumi hal secara umum dan khusus sebagai contoh amalan bagi individu Muslim. Antara contoh syariat secara muamalat yang terdapat dalam paparan gambar 9 A menggambarkan watak Uncle Maideen menyatakan roti yang dijual olehnya adalah halal untuk dimakan dan ia turut disokong dan dipuji oleh Ummi. Usaha Uncle Maideen sebagai penjual roti yang halal di Taman perumahan kawasan Pondok Ummi menunjukkan bahawa umat Islam patut berjihad dalam bidang ekonomi bahagian pemakanan.

Gambar 9 B dalam episod Lebah Membawa Manfaat memaparkan Alif yang menyatakan duit simpanannya telah disedekahkan kepada pengemis semasa ditanya oleh Ummi. Amalan baiknya itu kemudiannya dipuji oleh Ummi sebagai galakan untuk terus melakukan kebaikan kerana Allah SWT. Selain dari itu, aktiviti menabung di kalangan anak didik Ummi merupakan contoh amalan kepada penonton untuk menyimpan wang sejak dari kecil.

Manakala gambar $9 \mathrm{C}$ yang terdapat dalam episod Telaga Zam Zam pula memaparkan senarai rukun Islam sebagai penjelasan oleh watak Alif ketika Hana dan Aiman berusaha menghafal rukun Islam. Pendedahan ini merupakan pengetahuan asas bagi individu yang beragama Islam dan secara tidak langsung ia menggambarkan betapa pentingnya syariat tersebut sebagai panduan hidup bagi individu Muslim dalam Rukun Islam.

\section{iii. Akhlak}

Akhlak Islam merupakan cerminan dari akidah dan syariat. Ia merupakan budi pekerti ${ }^{28}$ individu yang mengamalkan ajaran agama Islam dengan mengikut panduan dari al-Quran dan Sunnah. Dalam erti kata lain, akhlak adalah roh kepada risalah Islam $^{29}$. Menurut Ibnu Miskawaih, akhlak ialah keadaaan jiwa yang mendorong timbulnya perbuatan-perbuatan secara $\operatorname{spontan}^{30}$ dan ia terbahagi kepada dua unsur sama ada secara kebiasaan naluri dan

${ }^{28}$ Hajah Noresah bt. Baharom, Kamus Dewan Edisi Keempat, 25.

${ }^{29}$ Haron Din et. al. Manusia dan Islam (Kuala Lumpur: Academy Art \& Printing Services Sdn. Bhd, 1995, 157.

30 Amir Sabri, "Pemikiran Ibnu Miskawaih", laman sesawang blogspot.com, dikemaskini Januari 2015, dicapai 19 April 2016, http://amirsabri.blogspot.my/2015/01/pemikiran-ibnu-miskawaih.html 
melalui latihan ${ }^{31}$. Oleh yang demikian, penerapan ilmu Islam dalam pendidikan kepada anak-anak adalah penting sebagai latihan asas yang mendorong kepada pembentukan akhlak yang mulia. Kandungan pembelajaran akhlak ${ }^{32}$ ini terbahagi kepada beberapa keadaan seperti adab individu dalam kehidupan seharian, adab bermasyarakat, adab dalam keluarga dan adab beragama terhadap Allah SWT dan rasulNya. Antara paparan akhlak yang terkandung dalam penerbitan siri UCPK ialah:

Gambar 10: Contoh gambaran akhlak yang ditonjolkan dalam siri UCPK.

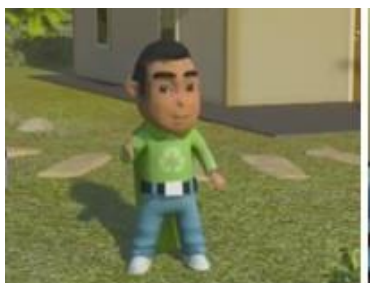

GAMBAR $10 \mathrm{~A}$

Episod 6: Iman Mengangkat Martabat

Masa: 03:35-03:43

Atan: Allah melarang

pembaziran. Kitar semula, kita dapat pahala.

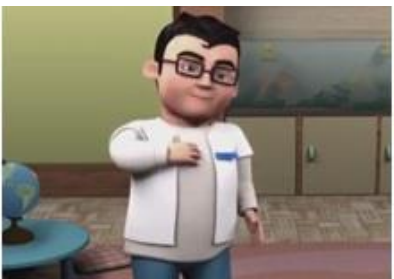

GAMBAR 10 B

Episod 6: Pemimpin Terpuji Masa: $15: 38-15: 47$

Alif: Alif ingin mengikut contoh yang ditunjukkan oleh Umar al-Khattab. Alif mahu menjadi ketua kelas yang berfikir mengenai kawan-kawan, bertanggungjawab dan jujur.

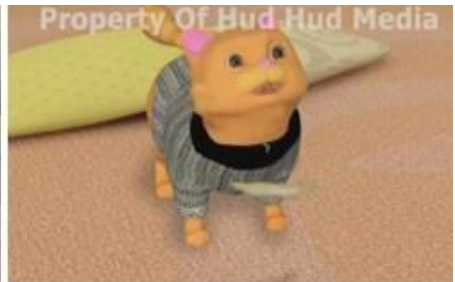

GAMBAR $10 \mathrm{C}$

Episod 9: Telaga Zam Zam

Masa: 04:36-04:42

Putri: Bismillahirrahmanirrahim. Makanlah Jojo.

Jojo: Meow, meow...

Alif: Putri, saya rasa kamu manjakan Jojo sangat.

Sumber: Hud Hud Media Sdn Bhd, 2011.

Akhlak bagi individu muslim terbahagi kepada hubungan adab dengan Tuhan, sesama manusia dan terhadap makhluk ciptaan Allah SWT yang lain seperti flora dan fauna. Antara contoh yang terdapat dalam gambar 10 A dalam episod Iman Mengangkat Martabat, menggambarkan watak Atan yang menyampaikan pesanan bahawa Allah melarang pembaziran. Secara tidak langsung kempen kitar semula ini juga merupakan

${ }^{31}$ Ibn Miskawaih, Tahzib al-Akhlaq, h. 265. Melalui Amir Sabri, "Pemikiran Ibnu Miskawaih", laman sesawang http://amirsabri.blogspot.my/2015/01/pemikiran-ibnu-miskawaih.html

${ }^{32}$ Asmawati Suhid, "Pengajaran Adab \& Akhlak Islam dalam Membangunkan Model Insan", Jurnal Pusat Pengajian Umum UKM (8 Disember 2007), 172173. 
salah satu cara untuk menjaga kebersihan kerana ia juga sebahagian dari iman.

Gambar 10 B dalam episod Pemimpin Terpuji pula menampilkan watak Alif yang menyatakan hasrat kepada ibu dan bapanya bahawa dia ingin membantu cikgu dan kawan-kawannya di sekolah berdasarkan jawatan yang dimilikinya sebagai ketua kelas. Hal ini terjadi selepas Ummi menceritakan kisah khalifah Umar Al-Khattab sebagai pemimpin untuk dijadikan sebagai contoh kepada anak didiknya.

Manakala dalam gambar $10 \mathrm{C}$ bagi episod Telaga Zam Zam, watak Jojo menerima makanan dari Putri selepas dinasihati agar jangan mencuri. Walaupun rakannya yang lain berpendapat bahawa Putri terlalu memanjakan Jojo, tetapi ia menggambarkan bahawa haiwan juga berhak untuk dikasihani dan disayangi.

\section{Cara Pendekatan dan Gaya Persembahan}

Pendekatan dakwah dan gaya persembahan saling berkait dalam proses perlaksanaan aktiviti dakwah. Teori pendekatan dakwah yang terdapat di dalam al-Quran Surah an-Nahl ayat $125^{33}$ mengandungi seruan secara Al-Hikmah, Maw'zatul Hasanah dan Mujaadalah secara teori. Gaya persembahan pula merupakan hasil terjemahan secara praktikal kepada kandungan seruan yang terdapat dalam pendekatan dakwah tersebut selain dari bertujuan untuk memberikan kefahaman yang lebih mudah. Berikut merupakan beberapa cara pendekatan dakwah dan gaya persembahan yang terdapat dalam siri UCPK:

A. Al-Hikmah: Merupakan suatu tindakan penyesuaian secara bijaksana terhadap sasaran dakwah supaya suasana tersebut boleh dikendalikan dengan baik dan tujuan dakwah yang berisi mesej kebaikan berjaya disampaikan. Antara contoh al-Hikmah yang digunakan adalah seperti berikut:

1. Lagu: Lagu ialah gubahan muzik pada kebiasaannya beserta dengan seni $\mathrm{kata}^{34}$ dalam bentuk lirik yang membawa mesej

\footnotetext{
${ }^{33}$ Sayyid Quthb, Tafsir Fi Zhilalil Qur'an, terj. As'ad Yasin, Abdul Aziz Salim Basyarahil, dan Muchotob Hamzah (Jakarta: Gema Insani, 2000; Terbitan asal: Beirut, Darusy-Syuruq, 2006), 7:224-225.

${ }^{34}$ Hajah Noresah bt. Baharom, Kamus Dewan Bahasa Edisi Keempat, 867.
} 
tertentu untuk menghiburkan pendengar. Selain dari penggunaannya sebagai bahan hiburan, ia juga boleh dijadikan untuk tujuan pendidikan kerana terdapat beberapa kajian membuktikan bahawa muzik bermanfaat kepada manusia dari sudut kesihatan dan kesejahteraan. ${ }^{35}$

Dalam setiap siri UCPK, lagu merupakan gaya persembahan utama yang dipaparkan sebagai daya tarikan kepada penonton. Antara komposer lagu, artis dan penulis lirik yang terlibat ialah Encik Johan Nawawi, Puan Nora Ariffin, Bringgo, Ustazah Faizah, Amran Omar dan ahli kumpulan Voices of Ummi (VOU). Setiap lagu-lagu yang disampaikan mempunyai nilai-nilai mesej dakwah kepada penonton mengikut tema tajuk seperti berikut:

Gambar 11: Contoh lagu yang terdapat dalam siri UCPK yang mengandungi adab dengan Allah, sesama manusia dan makhluk alam yang lain.

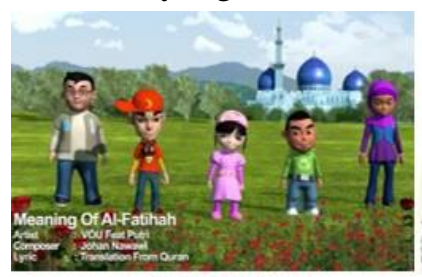

GAMBAR 11 A

Episod: Erti al Fatihah

Tajuk Lagu: Erti al Fatihah

Masa: 05:01-06:10

Lirik Lagu:

Segala puji bagi Allah

Tuhan semesta alam,

Maha Pemurah lagi Maha Penyayang.

Yang menguasai hari pembalasan...

Hanya kepadaMu, Ya Allah,

Kami menyembahMu, Ya Allah,

Hanya kepadaMu kami mohon pertolongan..

Tunjukilah kami jalan yang lurus,

Iaitu jalan orang-orang yang Kau kurniakan.

Nikmat kepada mereka,

Bukan jalan mereka yang dimurkai...

Dan bukan pula jalan mereka yang sesat.

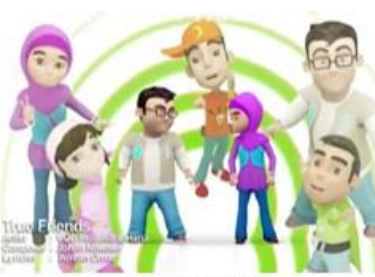

GAMBAR 11 B

Episod: Rakan Sejati

Tajuk Lagu: Rakan Sejati

Masa: 17:26-19:56

Lirik Lagu:

Hadirnya membuat hidup bermakna,

Pengorbanan darinya dengan sepenuh rela,

Menemani dikala sunyi,

Mengubati di kala duka,

Sentiasa membawa kita ke jalan yang benar...

Rakan sejati setia di sisi,

Tika jatuh tika berdiri,

Rakan sejati, jiwa yang murni,

Tiada pernah menyakiti,

Doanya yang sesuci ikhlas tika memberi,

Alhamdulillah.

Sungguh indah hati budi rakan sejati...

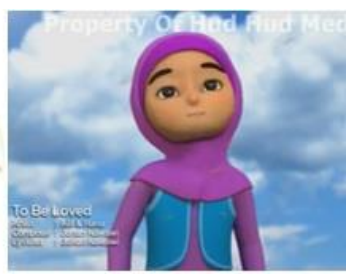

GAMBAR $11 \mathrm{C}$

Episod: Lebah Membawa Manfaat Tajuk Lagu: Sayangilah Masa: 02:05-03:06 Lirik Lagu:

Setiap Kehidupan Di Dunia,

Ciptaan Yang Esa,

Walaupun Sekecil Sebesar Mana,

Berbaiklah Kita.

Sayangilah, Setiap Makhluk Tuhan

Meskipun Cuma Ianya Haiwan

Menyayangilah,

Begitu besarnya hikmah,

Hidupkan Menjadi Indah. .

Sumber: Hud Hud Media Sdn Bhd, 2011.

${ }^{35}$ Muhammad Akhmal Hakim, Kecerdasan Membentuk Muslim Superior (Selangor: PTS Millennia Sdn Bhd., 2013), 176. 
Selain dari memiliki alunan melodi yang menarik, keseluruhan lirik yang terdapat dalam lagu juga mudah difahami. Ia merangkumi unsur-unsur akidah, seruan syariat dan akhlak dalam menjaga adab dengan Tuhan, sesama manusia dan makhluk ciptaan Allah SWT seperti flora dan fauna. Gambar 11 A antaranya merupakan contoh lagu yang paling tepat dalam seruan akidah dengan menggunakan terjemahan surah Al-Fātiḥah. Ia merupakan lirik yang mengagungkan Allah SWT sebagai Tuhan yang berhak untuk disembah dan menyatakan kesyukuran kita sebagai makhluk ciptaanNya.

Gambar 11 B bagi lagu yang bertajuk Rakan Sejati merupakan hubungan sesama manusia dalam bersahabat. Ia juga memberikan gambaran bahawa antara ciri-ciri sahabat sejati adalah dengan kesanggupan untuk bersama walaupun dalam keadaan susah dan senang. Ia juga merupakan lagu yang bersempena dengan tema cerita yang bertajuk rakan sejati. Manakala lagu yang terdapat dalam gambar $11 \mathrm{C}$ merupakan pesanan untuk kita sebagai manusia supaya menyayangi makhluk ciptaan Allah SWT walaupun ia kecil ataupun besar yang merangkumi flora dan fauna. Lagu pembuka ini merupakan tema untuk cerita bagi episod Lebah Membawa Manfaat.

2. Motivasi: Motivasi ialah sesuatu yang membuat atau mendorong seseorang berusaha atau melakukan sesuatu dengan penuh minat ${ }^{36}$ secara positif untuk melipatgandakan usaha dalam mencapai tujuan tertentu. ${ }^{37}$ Targhib dan Tarhib iaitu mendorong dan menakuti ${ }^{38}$ merupakan contoh motivasi yang digunakan dengan tujuan kebaikan dan menjauhkan keburukan. Rangsangan ini merupakan suatu bentuk dakwah yang memberikan galakan untuk melakukan kebaikan dengan menjanjikan ganjaran yang disukai oleh sasaran ${ }^{39}$. Antara babak yang terdapat dalam siri UCPK berkenaan dengan motivasi adalah seperti berikut:

\footnotetext{
${ }^{36}$ Hajah Noresah bt. Baharom, Kamus Dewan Bahasa Edisi Keempat, 1044.

${ }^{37}$ Nazneen Ismail, Psikologi Islam (Selangor: Must Read Sdn Bhd., 2014), 57.

${ }^{38}$ Muhammad Nur Abdullah Hafiz Suaid., Didik Anak Cara Rasulullah SAW (Kuala Lumpur: Klang Book Centre, 2006), 674.

39 Ab Aziz Mohd Zin, Metodologi Dakwah (Kuala Lumpur: Penerbit Universiti Malaya, 2001), 160.
} 
Gambar 12: Sebahagian dari paparan yang mengandungi unsurunsur motivasi.

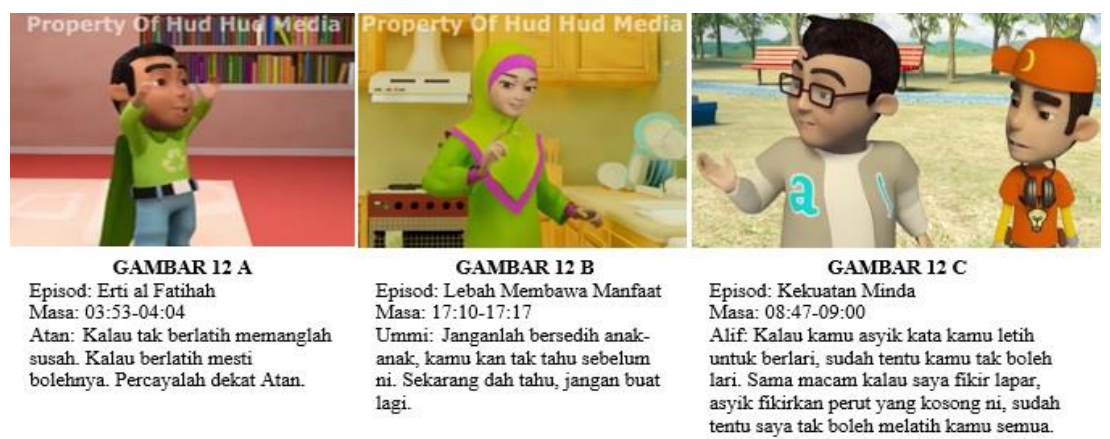

Sumber: Hud Hud Media Sdn Bhd, 2011.

Unsur-unsur motivasi yang terkandung dalam kesemua episod ini mengandungi pelbagai cara seperti galakan, pujukan dan cabaran untuk berusaha mengatasi masalah yang dihadapi oleh anak-anak didik Ummi. Kaedah motivasi yang diterapkan dalam pelbagai situasi menunjukkan bahawa motivasi yang dijana dengan pelbagai keadaan merupakan pengulangan secara langsung untuk membina cara berfikir dan menerapkan ia menjadi suatu kebiasaan kepada para penonton. Antara contoh unsur motivasi galakan terdapat dalam gambar 12 A yang menunjukkan watak Atan memberikan galakan kepada rakan-rakannya yang kelihatan kurang bersemangat untuk menghafal surah al fatihah disebabkan pelbagai prejudis sebelum melakukannya.

Gambar 12 B pula menggambarkan motivasi secara pujukan oleh watak Ummi terhadap anak didiknya, Atan dan Hana selepas merasa bersalah kerana telah membunuh semut. Pujukan ini merupakan suatu cara untuk mendorong anak didiknya agar tidak melakukan lagi kesilapan yang sama pada masa akan datang.

Motivasi kaedah cabaran yang terdapat dalam gambar $12 \mathrm{C}$ pula memaparkan watak Alif cuba memberikan semangat positif kepada Hana melalui perbandingan dengan dirinya agar tidak tenggelam dalam perasaan keletihan dan berusaha sebaik mungkin dalam melakukan sesuatu perkara. Kesemua bentuk motivasi yang dipaparkan bertujuan untuk memupuk minat terhadap perkara positif, mengulangi amalan-amalan yang baik, dan tidak mengenal erti putus asa serta menjadikan elemen-elemen tersebut sebagai 
sebahagian dari sifat jati diri individu terdapat dalam dalam semua episod UCPK.

3. Jenaka: Jenaka ialah perbuatan atau kata-kata yang membuat orang ketawa. ${ }^{40}$ Ia merupakan antara daya tarikan yang terdapat dalam gaya persembahan supaya penonton tidak bosan. Walaupun ia adalah rekaan, jenaka tidak dianggap sebagai pembohongan yang diharamkan. ${ }^{41}$ Ini kerana secara fitrahnya manusia dikurniakan perasaan untuk ketawa disamping berupaya untuk menjana peribadi yang positif dan menambah seri ${ }^{42}$ dalam kehidupan semasa. Berikut merupakan babak-babak jenaka yang terdapat dalam jalan cerita tersebut:

Gambar 13: Contoh paparan jenaka yang terdapat dalam siri UCPK.

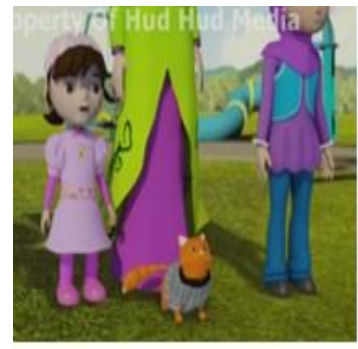

GAMBAR 13 A

Episod: Pemimpin Terpuji Masa: 06:51-07:03

Putri: OK. Jojo kata, Abang Alif nampak kurus sikit.

Alif: Hmm. Ni puji ke perli?

Lagipun, Alif bersenam sejak kebelakangan ni. Terima kasih Jojo.

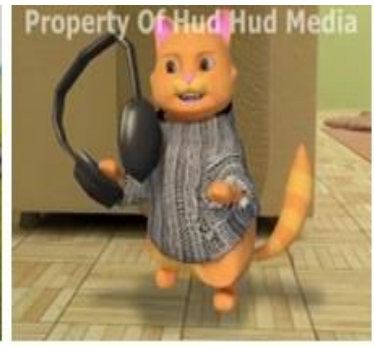

GAMBAR 13 B

Episod: Terima Kasih Cikgu

Masa: 03:16-03:21

Jojo: (Bersedia dengan headphone untuk menutup telinga kerana tidak tahan mendengar suara Putri menyanyi)

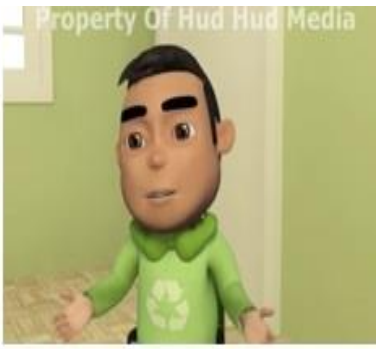

GAMBAR $13 \mathrm{C}$

Episod: Telaga Zam Zam Masa: 05:05-05:18 Atan: Kenapa tak ada orang tanya saya? Aiman: Kamu tahu ke Atan?

Atan: Sebenarnya saya tak tahu. Terima kasih sebab bertanya.

Sumber: Hud Hud Media Sdn Bhd, 2011.

Elemen jenaka yang didapati dalam keseluruhan siri episod UCPK berfungsi menjadikan jalan ceritanya menarik dan membina sifat positif dengan merangsang emosi ceria dan

\footnotetext{
${ }^{40}$ Hajah Noresah bt. Baharom, Kamus Dewan Bahasa Edisi Keempat, 623.

${ }^{41}$ Yusuf Qaradhawi, Fiqh Hiburan dan Rekreasi (Selangor: PTS Islamika Sdn Bhd., 2014), 45.

42 Yusuf Qaradhawi, Seni \& Hiburan dalam Islam. Cetakan ke-3 (Kuala Lumpur: Al-Hidayah Publications, 2008), 170.
} 
gembira. Rangsangan jenaka yang dipaparkan juga didapati sederhana dan tidak keterlaluan untuk membolehkan mesej utamanya disampaikan dengan berkesan kepada para penonton. Terdapat beberapa jenis jenaka yang antaranya berbentuk pujian, sindiran dan perhatian. Gambar 13 A misalnya adalah jenaka berbentuk pujian dengan memaparkan watak Putri yang menyatakan Jojo memberitahu Alif kelihatan sedikit kurus apabila Alif meminta Ummi, Hana dan Putri untuk meneka kelainan yang terdapat pada dirinya pada hari itu.

Jenaka berbentuk sindiran pula seperti dalam paparan gambar 13 B yang menunjukkan Jojo (Kucing) tidak tahan mendengar suara sumbang nyanyian Putri yang sedang berlatih untuk sambutan hari guru. Jojo kemudiannya bertindak menutup telinganya dengan headset sebagai penyelesaian walaupun secara realitinya kucing akan lari apabila terdengar suara yang terlalu kuat dan menyakitkan telinganya.

Bagi jenaka yang berbentuk perhatian seperti dalam paparan gambar $13 \mathrm{C}$, kelihatan watak Atan yang mengusik Atan dan Hana yang kelihatan berusaha untuk menghafal rukun Islam. Walaupun demikian, usikan tersebut adalah tidak keterlaluan apabila Atan juga dilihat cuba untuk membantu rakannya agar tidak terlalu menekan diri selain dari turut serta dalam mendengar cerita Ummi. Kesemua jenaka dalam siri UCPK didapati selari dengan jalan cerita dan turut mempunyai unsur pendidikan dan motivasi secara tidak langsung.

4. Model: Model ialah sesuatu atau seseorang yang dapat dijadikan contoh untuk ditiru atau diteladani. ${ }^{43}$ Albert Bandura menyatakan bahawa kebiasaan tingkah laku bagi manusia dipelajari melalui contoh model dalam empat perkara iaitu perhatian, pengekalan, perkembangan dan motivasi ${ }^{44}$. Peniruan tidak sekat lakuan merupakan antara satu dari pelbagai jenis model yang boleh ditonjolkan dalam semua situasi ${ }^{45}$ seperti berbudi bahasa dalam kehidupan harian. Ia juga merupakan suatu kaedah

${ }^{43}$ Hajah Noresah bt. Baharom, Kamus Dewan Bahasa Edisi Keempat, 1039.

${ }^{44}$ Catherine Collin et. al., The Psychology Book (London: Dorling Kindersley Limited, 2012), 288-289.

45 Mok Soon Sang, Psikologi Pendidikan untuk Pengajaran dan Pembelajaran (Selangor: Penerbitan Multimedia Sdn. Bhd., 2014), 287. 
pengulangan dalam proses pembelajaran secara praktikal yang berkesan untuk membentuk kebiasaan dalam diri manusia ${ }^{46}$ selain dari bertujuan untuk mengukuhkan ingatan.

Gambar 14: Contoh model hasil pembelajaran yang terdapat dalam siri UCPK.

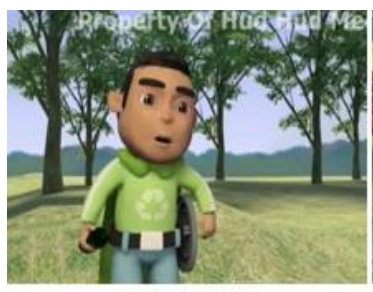

GAMBAR $14 \mathrm{~A}$

Episod: Iman Mengangkat Martabat Masa: 18:53-19:07

Atan: Tak apalah. Mereka cumalah orang yang jahil. Allahu Akbar (3x). Allah tak memandang rupa dan harta.

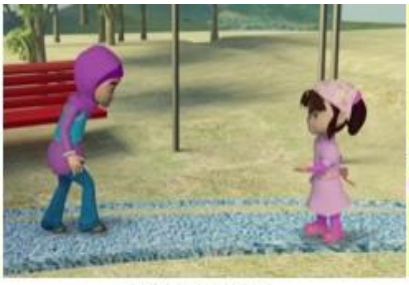

\section{GAMBAR 14 B}

Episod: Kekuatan Minda

Masa: 20:02-20:15

Hana: Kenapa datang semula? Kamu kan dah jauh ke depan sekarang? Nanti kamu tak menang.

Putri: Tak apa. Inikan larian amal.

Membantu kawan juga kan dikira sebagai ibadah.

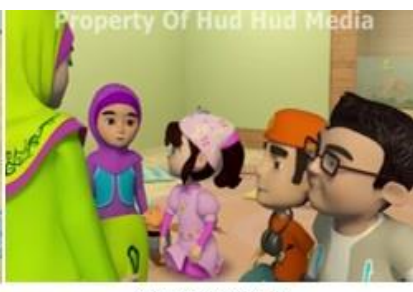

GAMBAR 14 C

Episod: Terima Kasih Cikgu Masa: 15:41-15:49

Hana: Saya dah tak nak bergaduh lagi. Alif, maafkan saya. Kita jangan bergaduh lagi ye.

Alif: Saya pun sama.

Sumber: Hud Hud Media Sdn Bhd, 2011.

Watak Alif, Aiman, Hana, Atan dan Putri dalam bentuk kanak-kanak dilihat sebagai model utama yang mempraktikkan ilmu-ilmu yang telah dipelajari dari watak Ummi. Ini menunjukkan bahawa watak-watak yang dicipta dalam siri ini bertujuan untuk mewujudkan perasaan yang sama melalui personaliti yang dipaparkan kepada penonton sendiri terutamanya terhadap golongan kanak-kanak. Bentuk model yang dipaparkan adalah didasari dengan akidah, syariat dan akhlak.

Gambar 14 A merupakan contoh bagi model kelakuan dalam menjaga adab dengan Tuhan seperti watak Atan yang sudah tidak peduli lagi akan ejekan budak-budak nakal setelah mendengar kisah Bilal bin Rabah yang lebih mengutamakan iman dari segala hal dunia. Gambar 14 B pula memaparkan kelakuan Putri yang membantu Hana dalam latihan larian amal yang dianjurkan oleh sekolah. Nilai utama yang ingin ditonjolkan bukanlah untuk memenangi pertandingan dalam larian, tetapi kepada keikhlasan

\footnotetext{
${ }^{46}$ Nazneen Ismail, Psikologi Islam, 61.
} 
dalam melakukan ibadah menjaga kesihatan dan perhubungan sesama manusia kerana Allah SWT.

Model bagi gambar $14 \mathrm{C}$ pula menggambarkan contoh agar sentiasa dalam keadaan berlapang dada untuk memohon dan memberi maaf apabila melakukan kesilapan dalam kehidupan harian. Secara jelas, penyampaian watak-watak tersebut dalam bentuk perbualan, kelakuan dan pemakaiannya boleh ditiru dan menjadi rujukan dalam membina identiti individu yang dilihat mempunyai sifat-sifat yang positif selain dari bertujuan untuk menjadikan cerita tersebut difahami dengan mudah.

B. Maw'izat al-Hasanah: Ia merupakan ungkapan yang mengandungi unsur bimbingan yang antaranya dalam bentuk penceritaan, pendidikan, dan pesanan ke arah kebaikan. Berikut merupakan beberapa contoh yang menggambarkan cara Maw izat al-Hasanah dilaksanakan dalam siri UCPK:

1. Penceritaan: Cerita ialah karangan atau lakonan yang mengisahkan sesuatu peristiwa sama ada secara rekaan atau berdasarkan kejadian yang sebenar. ${ }^{47}$ Pendekatan ini berupaya menarik perhatian, mengajak sasaran untuk berfikir dan mengambil iktibar dari cerita masa lalu ${ }^{48}$ supaya boleh menjadikannya sebagai panduan dalam kehidupan. Berikut merupakan cerita-cerita yang terkandung dalam setiap episod siri UCPK:

\footnotetext{
${ }^{47}$ Hajah Noresah bt. Baharom, Kamus Dewan Bahasa Edisi Keempat, 272.

${ }^{48}$ Muhammad Nur Abdullah Hafiz Suaid, Didik Anak Cara Rasulullah SAW, 694.
} 
Gambar 15: Contoh kandungan cerita yang mengandungi manfaat, pengajaran dan ilmu pengetahuan dalam siri UCPK.

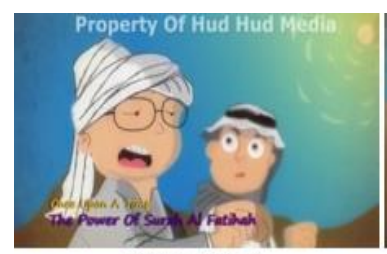

GAMBAR 15 A

Episod: Erti al Fatihah

Tajuk Cerita: Kelebihan Surah A1

Fatihah

Masa: 06:53-11:31

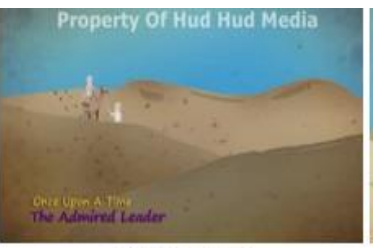

GAMBAR 15 B

Episod: Pemimpin Terpuji

Tajuk Cerita: Pemimpin Terpuji

Masa: 08:37-12:35

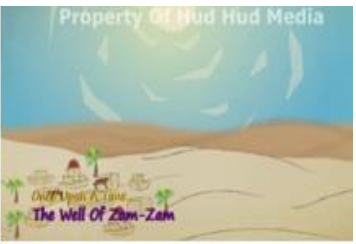

GAMBAR 15 C

Episod: Telaga Zam Zam

Tajuk Cerita: Telaga Zam Zam

Masa: 09:42-17:11

Sumber: Hud Hud Media Sdn Bhd, 2011.

Konsep utama yang dibawakan dalam siri UCPK ini adalah berkenaan cerita-cerita yang dipaparkan mempunyai manfaat, teladan dan ilmu pengetahuan bagi para penonton. Antara contoh kisah yang membawa manfaat adalah seperti dalam gambar $15 \mathrm{~A}$ yang membawakan kisah al-Fatihah sebagai tonggak utama bagi setiap Muslim untuk mengamalkannya dalam solat, doa dan lainlain amalan beserta dengan bacaan tajwid yang betul.

Gambar 15 B pula merupakan contoh kisah yang memaparkan teladan dari Umar al Khattab yang boleh dicontohi oleh para penonton apabila menjadi pemimpin. Antara kualiti kepimpinan yang terdapat dalam diri Umar al-Khattab dalam episod ini ialah bersifat merendah diri, bertanggungjawab, prihatin dengan keadaan pengikut yang dipimpin dan sentiasa membantu pihak yang memerlukan pertolongan.

Bagi episod Telaga Zam Zam yang dipaparkan dalam gambar $15 \mathrm{C}$ pula merupakan antara contoh kisah yang memberikan ilmu pengetahuan kepada para penonton. Selain dari memaparkan sejarah kewujudan Kota Mekah yang berpunca dari Telaga Zam Zam, ia juga memberikan ilmu pengetahuan yang berkaitan dengan Rukun Islam dan inspirasi kecekalan Siti Hajar dalam bertawakal kepada Allah SWT.

2. Pendidikan: Pendidikan sinonim dengan perihal didikan, latihan atau ajaran ${ }^{49}$ dan merupakan aktiviti-aktiviti yang berkaitan

\footnotetext{
${ }^{49}$ Hajah Noresah bt. Baharom, Kamus Dewan Bahasa Edisi Keempat, 350.
} 
dengan pembentukan, perkembangan ilmu, kemahiran, kerohanian dan jasmani manusia. ${ }^{50}$ Dalam konteks dakwah, pendidikan bertujuan untuk menjadikan sasaran mempunyai ilmu pengetahuan, akhlak yang mulia dan kemahiran tertentu dalam menyesuaikan diri dengan masyarakat semasa. Antara paparannya adalah seperti berikut:

Gambar 16: Segmen kalimah pilihan yang mengajar penonton beberapa perkataan baharu sebagai bahan pendidikan.

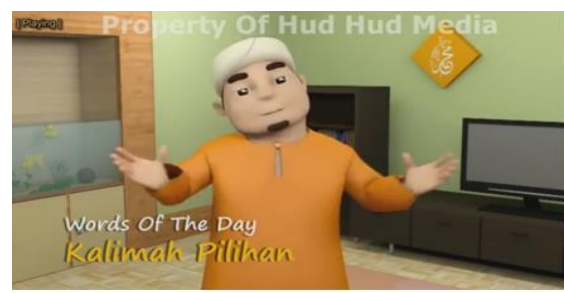

Segmen Kalimah Pilihan (Pembuka)

Ustaz Syakir:

Assalamualaikum warahmatullahi wa barakatuh. Saya Ustaz Syakir. Sekarang mari kita mengingat kembali beberapa kalimah pilihan.

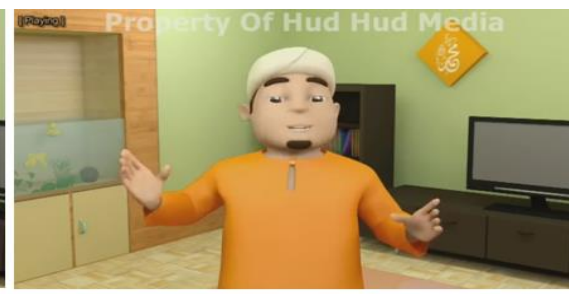

Segmen Kalimah Pilihan (Penutup) Ustaz Syakir:

Demikianlah kalimah-kalimah yang adikadik pelajari pada Episod Ummi ini. Ingat ya, dan gunalah kalimah dengan tepat.

Sumber: Hud Hud Media Sdn Bhd, 2011.

Segmen kalimah pilihan merupakan paparan yang menonjolkan elemen pendidikan secara langsung kepada penonton. Secara purata, terdapat tiga perkataan baru dalam setiap episod yang dipaparkan melalui watak Ustaz Syakir. Di samping perkataan baru atau kalimah pilihan, terdapat penerangan yang lengkap beserta contoh yang sesuai untuk difahami oleh kanakkanak. Ayatnya juga ringkas dan padat seperti senarai berikut:

${ }^{50}$ Mok Soon Sang, Psikologi Pendidikan untuk Pengajaran dan Pembelajaran, 7. 


\begin{tabular}{|l|l|}
\hline Kategori & \multicolumn{1}{|c|}{ Perkataan } \\
\hline Akidah & $\begin{array}{l}\text { La Ilaha ill Allah: Tiada tuhan melainkan Allah. Kita } \\
\text { selalu menggunakan ayat ini apabila dalam Solat } \\
\text { Tahiyat Akhir sebagai pengakuan hanya Allah yang } \\
\text { layak disembah. }\end{array}$ \\
\hline Syariat & $\begin{array}{l}\text { Ibadah: Menyerah diri untuk beribadah kepada Allah. } \\
\text { Ibadah terdiri dari pelbagai perbuatan yang tertentu } \\
\text { seperti solat dan puasa. Begitu juga ibadah umum } \\
\text { yang di mana perbuatan tersebut baik dilakukan } \\
\text { kerana Allah. Seperti contoh mempelajari ilmu } \\
\text { pengetahuan, berbakti kepada masyarakat, mencari } \\
\text { rezeki halal, bersenam dan lain-lain lagi. }\end{array}$ \\
\hline Akhlak & $\begin{array}{l}\text { Akhlak: Amalan kebajikan secara realiti dan beradab. } \\
\text { Ia menggambarkan perwatakan, kelakuan dan } \\
\text { perbuatan. Dalam Islam, akhlak berkait dengan } \\
\text { persekitaran kita sama ada sesama manusia, haiwan, } \\
\text { alam sekitar ataupun terhadap Allah SWT. Rasulullah } \\
\text { SAW terkenal dengan akhlak yang terbaik. Oleh itu, } \\
\text { kita perlu mencontohinya dalam kehidupan harian } \\
\text { kita. }\end{array}$ \\
\hline
\end{tabular}

Sumber: Hud Hud Media Sdn Bhd, 2011.

3. Pesanan: Pesanan ialah amanat, nasihat atau suruhan ${ }^{51}$ yang mengandungi mesej peringatan yang tertentu kepada penerima. Dalam konteks dakwah, pesanan ialah ucapan berupa arahan kepada sasaran terhadap sesuatu perkara yang belum terjadi ${ }^{52}$ atau telah terjadi supaya ia tidak berulang. Tujuan pesanan adalah untuk membawa kebaikan dan menjauhkan perkara buruk dalam kehidupan. Ia juga mengandungi nilai kasih sayang, kebenaran dan kesabaran dalam proses pesanan tersebut. Berikut merupakan beberapa pesanan yang terkandung dalam siri UCPK:

\footnotetext{
${ }^{51}$ Hajah Noresah bt. Baharom, Kamus Dewan Bahasa Edisi Keempat, 1196.

${ }^{52}$ M. Munir et. al., Metode Dakwah (Jakarta: Kencana Prenada Media Group, 2009), 274.
} 
Gambar 17: Contoh paparan yang mengandungi amanat, suruhan dan nasihat dalam siri UCPK.

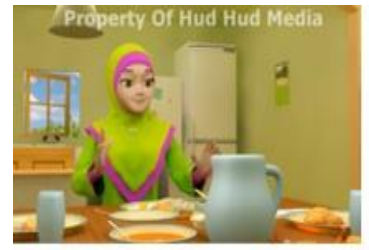

GAMBAR 17 A

Episod: Lebah Membawa Manfaat Masa: 06:02-06:14

Ummi: Ingat, kita mesti mengasihi semua makhluk Allah yang hidup. Setiap dari mereka diciptakan dengan tujuan tertentu sama ada kita tahu atau pun tidak.

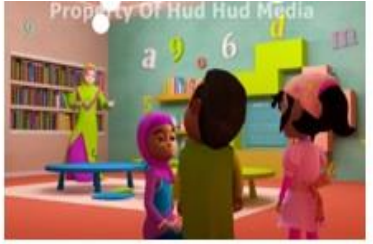

GAMBAR 17 B

Episod: Si Tanggang Moden Masa: 06:43-06:51

Ummi: Atan, Putri. Kan Ummi selalu pesan, tak elok berlari dalam rumah. Nasib baik tak melayang Kak Hana. baik awak berdua minta maaf.

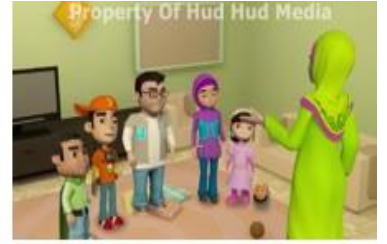

GAMBAR $17 \mathrm{C}$

Episod: Terima Kasih Cikgu Masa: 07:30-07:47

Ummi: Jangan biarkan niat baik kamu dirosakkan dengan sikap tidak sabar. Apabila kamu semua buat bekerjasama dan buat yang terbaik, sudah tentu ada cabarannya. Dan cabaran ini akan menguji kesabaran kita. Jadi kamu mesti kena kuat dan buat yang terbaik.

Sumber: Hud Hud Media Sdn Bhd, 2011.

Ummi merupakan watak sebagai pendidik kepada lima kanak-kanak bernama Alif, Aiman, Hana, Atan dan Putri. Sebagai pendidik, pesanan beliau selalu dipaparkan dalam pelbagai bentuk sama ada secara amanat, suruhan dan nasihat. Bahasa yang digunakan kelihatan sopan, bernada lembut dan susunan ayat juga dilihat ringkas dan mudah untuk difahami oleh para penonton.

Gambar 17 A merupakan antara contoh pesanan yang berbentuk amanat. Pesanan secara langsung ini terjadi apabila Atan membunuh semut yang terdapat pada pinggan Hana. Pengulangan pesanan ini juga berlaku di akhir cerita apabila Atan dan Hana rasa bersalah membunuh semut tersebut. Manakala pesanan berbentuk suruhan terdapat dalam gambar 17 B iaitu dengan memaparkan Atan dan Putri disuruh oleh Ummi untuk meminta maaf kepada Hana apabila mereka telah melanggarnya.

Pesanan berbentuk nasihat seterusnya memaparkan gambar $17 \mathrm{C}$ dalam keadaan Ummi memberikan nasihat kepada anak didiknya yang bergaduh dalam sesi latihan persembahan hari guru di sekolah. Selain dari nasihat, Ummi turut membawakan kisah pergaduhan bangsa arab jahiliyyah dalam peristiwa perletakan hajarul aswad sebagai contoh yang akhirnya kisah ini menginsafkan mereka untuk tidak bergaduh lagi apabila melakukan kerja dalam berkumpulan. 
C. Mujādalah: Berasal dari perkataan jaadala dalam bahasa Arab yang membawa maksud dari segi istilahnya iaitu mengikat dengan menggunakan sesuatu dengan kuat. ${ }^{53}$ Dalam erti kata bahasa melayu mujaadalah ialah berdebat atau berbahas ${ }^{54}$. Walaupun demikian, berbahas yang dibenarkan menurut seruan yang terkandung dalam al-Quran ialah secara baik. Ia bertujuan untuk bertukar pendapat dalam memberikan pandangan terhadap sesuatu perkara. Dalam hal ini, mujaadalah terbahagi kepada dua bentuk komunikasi seperti:

1. Perbualan: Merujuk kepada perihal berbual atau percakapan atau perkara yang dibualkan ${ }^{55}$. Ia merupakan komunikasi yang membolehkan orang memberi maklum balas secara terus antara satu sama lain ${ }^{56}$. Antara perbualan yang terdapat dalam siri UCPK adalah seperti berikut:

Gambar 18: Contoh komunikasi melalui perbualan untuk pembelajaran dan perbualan biasa yang terdapat dalam siri UCPK.

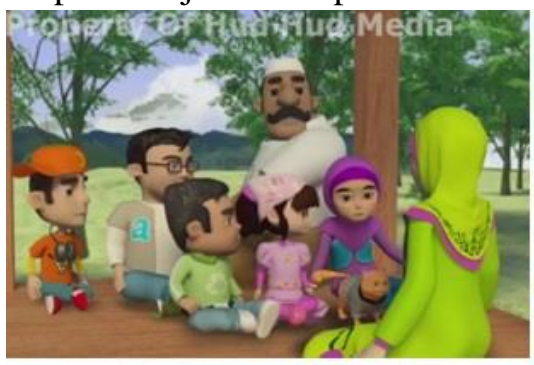

GAMBAR 18 A

Episod: Iman Mengangkat Martabat Masa: $15: 56-16: 31$

Putri: Putri kesian pada Bilal. Kenapa Umaiyyah sangat kejam padanya? Jojo pun takut.

Hana: Umaiyyah orang yang jahil. Nasib baik Abu Bakar ada untuk bebaskan Bilal.

Ummi: Alhamdulillah. Dalam Islam adalah tugas kita untuk membantu mangsa yang tertindas. Dan dalam Islam, kita tidak perlu bimbang paras rupa fizikal dan kekayaan harta benda. Apa yang penting ialah hati yang suci, iman yang kuat akan mengangkat martabat kita di mata Allah SWT.

Sumber: Hud Hud Media Sdn Bhd, 2011.

\footnotetext{
${ }^{53}$ M. Munir et. al., Metode Dakwah, 17.

${ }^{54}$ Hajah Noresah bt. Baharom, Kamus Dewan Bahasa Edisi Keempat, 322.

${ }^{55}$ Hajah Noresah bt. Baharom, Kamus Dewan Bahasa Edisi Keempat, 208.

${ }^{56}$ Zawiyah Mohammad Yusof, Kemahiran Komunikasi (Kuala Lumpur: Dewan Bahasa dan Pustaka, 2009), 11.
} 
Perbualan yang terdapat dalam siri UCPK ini memaparkan komunikasi dua hala secara formal dan tidak formal. Antara contoh perbualan formal adalah seperti dalam gambar $18 \mathrm{~A}$ mengenai kisah perbualan dan perbincangan tentang Bilal bin Rabah yang diajukan oleh Putri dan dijawab oleh Hana dan Ummi. Bagi perbualan tidak formal pula terdapat dalam gambar $18 \mathrm{~B}$ yang memaparkan Putri dan Ummi mengagumi keindahan pelangi ciptaan Allah SWT. Secara keseluruhan, bahasa perbualan yang digunakan adalah sopan dan sesuai untuk diamalkan dalam kehidupan harian.

2. Perdebatan: Perdebatan atau perbahasan secara baik merupakan bentuk komunikasi yang menunjukkan gaya bahasa dan budi pekerti yang sopan. Selain dari menggalakkan kanakkanak untuk bertutur dengan lancar, ia juga berfungsi untuk mengajak para penonton berfikir dan memahami topik yang cuba disampaikan dalam setiap siri episod UCPK. Berikut merupakan beberapa contoh berdebat yang terdapat dalam paparan tersebut:

Gambar 19: Contoh mujaadalah berbentuk perbincangan untuk tujuan pembelajaran dalam siri UCPK.

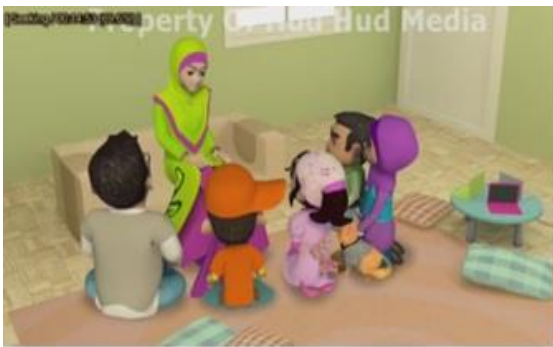

GAMBAR 19 A

Episod: Terima Kasih Cikgu

Masa: $14: 53-15: 23$

Putri: Ummi, Putri ada satu soalan, kenapa yang lain tak marah apabila Rasulullah yang meletakkan Hajarul Aswad? Hana: Ye lah, bukannya nak kiamat pun. Diorang macam budak-budak, Ummi.

(Semua ketawa)

Ummi: Itulah kenyataannya, Hana. Sebenarnya mereka tidak kisah pasal batu tu, tapi apabila kesabaran itu hilang, perkara kecil pun boleh menjadi hal yang besar.

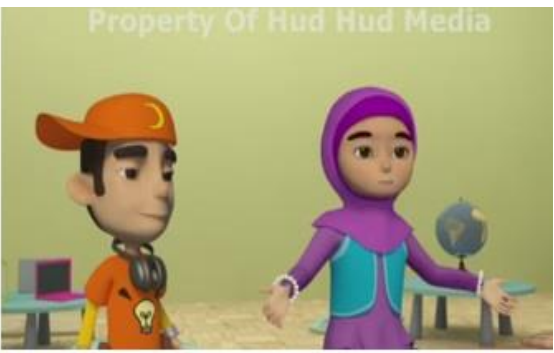

Episod: Telaga Zam Zam

GAMBAR 19 B

Masa: 18:39-19:07

Putri: Ummi, adakah Nabi Ibrahim pulang semula ke pangkuan Hajar dan Ismail?

Ummi: Wallahualam. Tapi bila Nabi Ibrahim bertemu semula dengan Ismail, dia telah pun dewasa dan Hajar telah meninggal dunia.

Hana: Kesiannya. Hajar marah tak kat suaminya?

Ummi: Hajar menerima takdir Allah. Hana, kamu tak rasa kesian dekat Nabi Ibrahim juga? Baginda kena tinggalkan isteri dan anaknya yang tercinta.

Sumber: Hud Hud Media Sdn Bhd, 2011. 
Perdebatan merupakan pendekatan yang menggalakkan kanak-kanak untuk berkeyakinan dalam berkomunikasi dengan rakan dan individu luar masyarakat semasa apabila terlibat dalam komunikasi dua hala yang memerlukan persoalan dan jawapan. Walaupun topik perbincangan yang membawa kepada mujaadalah dalam siri UCPK tidak berat, ia adalah permulaan untuk mengajak penonton berfikir dan faham dengan ilmu pengetahuan yang dipelajari. Antara contoh perdebatan secara sopan dipaparkan dalam gambar 19 A dan 19 B yang mengutarakan isi utama disebalik kisah perletakan hajarul aswad dan pengorbanan Nabi Ibrahim dan Siti Hajar dalam kisah Telaga Zam Zam.

\section{Penutup}

Hasil penelitian terhadap keseluruhan episod yang terdapat dalam siri Ummi musim pertama ini didapati menepati piawaian animasi dakwah berdasarkan kepada plot cerita, kriteria watak, dialog dan lagu-lagu yang terkandung di dalamnya. Penerbitan siri Ummi ini dilihat membawa mesej dalam persembahan animasinya dengan mengajak para penonton untuk mempelajari, memahami dan menghayati ajaran Islam dalam bentuk yang mudah difahami. Hampir keseluruhan dialog dan lagu-lagu yang terkandung di dalamnya mengandungi isi yang bersumberkan ajaran al-Quran, hadith, kisah para rasul, para sahabat dan teladan masyarakat. Cara penyampaian yang diterapkan juga mengandungi unsur-unsur psikologi untuk merangsang visual, pendengaran dan pemikiran penonton melalui muzikal yang menarik, pujukan dan motivasi ke arah sifat positif. Oleh kerana siri UCPK musim pertama ini memenuhi kriteria asas ajaran Islam yang terdiri dari unsur akidah, syariat dan akhlak, maka secara tidak langsung, produk animasi terbitan HHM ini merupakan animasi dakwah yang mempunyai peranannya yang tersendiri dalam menyebarkan ajaran Islam menerusi usaha dakwah kreatifnya.

\section{Bibliografi}

"A Legacy that Touched the Heart of a Nation: Featuring Terry Fox Athlete Article", Youth Education Programs, Honouring the Past. Inspiring the Future, dicapai 15 April 2016, http://www.heroinyou.ca/wp-content/uploads/2013/11/TerryFox-Athlete-Article.pdf 
"Asal Mula Air Zam-Zam dan Manfaatnya", dikemaskini 20112014, dicapai 15 April 2016, http://dakwahsyariah.blogspot.my /2013/09/asal-mula-air-zam-zam-dan-manfaatnya.html.

"Bilal Ibn Rabah", laman sesawang Islamreligion.com, dikemaskini 2013, dicapai 15 April 2016, http://islam114.com /main/wp-content/uploads/2013/07/Bilal-Ibn-Rabah.pdf.

Ab Aziz Mohd Zin. Metodologi Dakwah. Kuala Lumpur: Penerbit Universiti Malaya, 2001. 60.

Ab. Aziz Mohd Zin. Pengantar Dakwah Islamiah. Kuala Lumpur: Penerbit Universiti Malaya, 1997.

Abdul Karem Zaidan. Dasar-Dasar Ilmu Da'wah, terj. H.M Asywadi Syukur Lc. Selangor: Dewan Pustaka Fajar, 2007.

Abdul Latip Talib. Umar Al Khattab - Reformis Dunia Islam. Selangor: PTS Litera Utama Sdn Bhd., 2010.

Abdul Razak Muthalib. 40 Hadis Palsu Popular. Selangor: PTS Islamika Sdn Bhd. 2011.

Ahmad Tarmizi Talib. Tamadun Islam. Serdang: Penerbit Universiti Putra Malaysia. 1997..

Amir Sabri, "Pemikiran Ibnu Miskawaih", laman sesawang blogspot.com, dikemaskini Januari 2015, dicapai 19 April 2016, http://amirsabri.blogspot.my/2015/01/pemikiran-ibnumiskawaih.html

Amir Sabri, "Pemikiran Ibnu Miskawaih", laman sesawang http:// amirsabri.blogspot.my/2015/01/pemikiran-ibnu-miskawaih.html

Asmawati Suhid, "Pengajaran Adab \& Akhlak Islam dalam Membangunkan Model Insan", Jurnal Pusat Pengajian Umum UKM (8 Disember 2007), 172-173.

Catherine Collin et. al. The Psychology Book. London: Dorling Kindersley Limited, 2012.

Danial Zainal Abidin. Perubatan Islam dan Bukti Sains Moden. Selangor: PTS Millennia Sdn Bhd. 2015..

Fathi Yakan. Apa Ertinya Saya Menganut Islam?. Kuala Lumpur: Pustaka Salam Sdn Bhd., 2000.

Hajah Noresah bt. Baharom. Kamus Dewan Edisi Keempat. Kuala Lumpur: Dewan Bahasa dan Pustaka, 2015.

Haron Din et. al. Manusia dan Islam. Kuala Lumpur: Academy Art \& Printing Services Sdn. Bhd, 1995.

Jamalludin Harun dan Zaidatun Tasir. Animasi dari Helaian kertas ke Skrin Digital. Selangor: Venton Publishing, 2005. 
Ji Chen (Associated Press Researcher), "Liu Wei, Armless Pianist, Plays With His Toes, Wows Audience (VIDEO)", TheHuffingtonPost.com Inc, dikemaskini 25 Mei 2011, dicapai 15 April 2016, http://www.huffingtonpost.com/2010/08/27 /chinese-musician-with-no-_n_696914.html.

Kate Dudding, "The Sweetest Sound", laman sesawang katedudding.com, dicapai 15 April 2016, http://www.kate dudding.com/sweetest_sound.shtml

Kennedy, John M. and Juricevic, I. Esref Armagan and Perspective in Tactile Pictures. Kanada: University of Toronto, t.t.

Lc, Ahmad Sabiq, "Kisah al Qamah Durhaka Kepada Ibunya", laman sesawang Kisah Muslim, dikemaskini 25 November 2010, dicapai 23 Mac 2016, https://kisahmuslim.com/84alqomah-durhaka-kepada-ibu.html.

M. Abdul Ghaffar E.M, Abdurrahim Mu'thi, Abu Ihsan Al-Atsari, Tafsir Ibnu Katsir. Lubaabut Taafsiir Min Ibni Katsiir. Indonesia: Pustaka Imam Asy-Syafi'i, 2007.

M. Munir et. al. Metode Dakwah. Jakarta: Kencana Prenada Media Group, 2009.

Merriam-Webster. Online Dictionary. United States: An Encyclopedia Britannica, 1996, dicapai 25 Mac 2015, http:// www.merriamwebster.com/dictionary/animated\%20cartoon

Mok Soon Sang. Psikologi Pendidikan untuk Pengajaran dan Pembelajaran. Selangor: Penerbitan Multimedia Sdn. Bhd., 2014..

Muhammad Akhmal Hakim. Kecerdasan Membentuk Muslim Superior. Selangor: PTS Millennia Sdn Bhd., 2013..

Muhammad Nur Abdullah Hafiz Suaid. Didik Anak Cara Rasulullah SAW. Kuala Lumpur: Klang Book Centre, 2006.

Sayyid Quthb. Tafsir fi Zhilalil Qur'an, terj. As'ad Yasin, Abdul Aziz Salim Basyarahil, dan Muchotob Hamzah. Jakarta: Gema Insani, 2000; Terbitan asal: Beirut. Darusy-Syuruq, 2006.

Tarikuddin bin Haji Hassan. Kisah 25 Nabi-Nabi. Johor Bahru: Perniagaan Jahabersa, 2006.

Ummu Fatimah Az-Zahra. Riwayat Para Sahabat Rasulullah SAW. Johor: Perniagaan Jahabersa, 1998.

Yusuf al-Qaradhawi. Fiqh Hiburan dan Rekreasi. Selangor: PTS Islamika Sdn Bhd., 2014. 
Yusuf Qaradhawi. Fiqh Hiburan dan Rekreasi. Selangor: PTS Islamika Sdn Bhd., 2014.

Yusuf Qaradhawi. Seni dan Hiburan dalam Islam. Cetakan ke-3. Kuala Lumpur: Al-Hidayah Publications, 2008.

Zawiyah Mohammad Yusof. Kemahiran Komunikasi. Kuala Lumpur: Dewan Bahasa dan Pustaka, 2009. 